\title{
The Role of Most at-Risk Populations Coordinator in HIV-AIDS Prevention
}

\author{
Setya Haksama ${ }^{1 *}$, M. Farid Dimjati Lusno ${ }^{2}$, Anis Wulandari ${ }^{3}$, Syahrania Naura \\ Shedysni ${ }^{4}$, M. Rifqo Hafidzudin Farid ${ }^{5}$, Abdul Fattah Farid ${ }^{6}$, Syadza Zahrah Shedyta ${ }^{7}$ \\ ${ }^{1,2,3}$ Faculty of Public Health, Universitas Airlangga, Surabaya, Indonesia \\ ${ }^{4,5}$ Faculty of Medicine, Universitas Airlangga, Surabaya, Indonesia \\ ${ }^{6}$ Faculty of Pharmacy, Universitas Airlangga, Surabaya, Indonesia \\ ${ }^{7}$ Husada Utama Hospital, Surabaya, Indonesia \\ *Corresponding author. Email: setyahaksama@fkm.unair.ac.id
}

\begin{abstract}
HIV / AIDS as one of infectious diseases that has become endemic in 34 provinces in Indonesia. The number of new HIV cases based on Most at Risk Populations (MARPs) in Indonesia always increasing since year 2011 until 2016. The study aim to examined the role of HIV MARPs coordinator in preventing HIV. There were three main MARPs coordinator were examined using in-depth semi-structured interviewed. They were the coordinator of drug user, coordinator of shemale, and coordinator female sex workers. The data analysed using content analysis. HIV Prevention among the coordinator of MARPs has been important role especially by showing their empathy to motivate the HIV suspect or patient to access the public health care. However, the perception among the society will affect the perception of MARP's to go for accessing public health care service. The closeness between MARPs and the coordinator build the dependency from the member to the coordinator. MARPs coordinator play an important role in reaching out and assisting people at risk of contracting HIV / AIDS which include in coordinating the population at risk of HIV to get public health care service. The coordination need to outreach larger MARPs so that the public health care or the health department can give more information about HIV.
\end{abstract}

Keywords: MARP's coordinator, HIV/AIDS, prevention, role

\section{INTRODUCTION}

Human Immunodeficiency Virus (HIV) is a disease that attacks the human immune system. The form of transmission of this disease is one of them from an agent where the disease more easily spread among the community. According to the United Nations Acquired Immunodeficiency Syndrome (UNAIDS) globally, in 2013 there were 12.9 million cases, in 2014 there were 15.0 cases and in 2015 there were 17.0 million cases. Indonesia ranks as third after India and China. There were 2.3 million new cases of HIV infection and at the same time the number of deaths due to AIDS was stated to be 1.6 million in 2015. HIV and AIDS in Indonesia have entered a very alarming stage1.

According to data from the Ministry of Health since 2005 to September 2015, there were 184,929 HIV cases obtained from HIV testing and counseling services. The highest number of HIV cases were in DKI Jakarta (38,464 cases), East Java (24,104 cases), Papua (20,147 cases), West Java (17,075 cases) and Central Java (12,267 cases). HIV cases in July - September 2015 were 6,779 cases. The highest HIV transmission factors were unprotected sex in heterosexuals group $(46.2 \%)$, the use of unsterile needles $(3.4 \%)$ and men sex with men $(24.4 \%)$ [1].
The increase of HIV / AIDS incidents in East Java Province is no different from what happened in Indonesia, even the percentage of HIV / AIDS sufferers in East Java is slightly below West Java which is the largest infected population in Indonesia. In addition, the average death rate of people with HIV / AIDS in East Java is above the average death rate that occurred in Indonesia which indicates that the level of prevention of HIV / AIDS infectious diseases in East Java is still less attention [2].

Sidoarjo Regency, as the surrounded area of Surabaya city, has the same concerns because the incidence of HIV / AIDS in Sidoarjo Regency has increased sharply. The number of AIDS cases by residence in East Java Province shows that Sidoario regency is ranked second after the city of Surabaya until June 2012. The spread of HIV / AIDS has even spread in almost various regions in Sidoarjo. This increase was accompanied by an increasing number of Female Sex Workers (WPS) in Sidoarjo [3].

HIV / AIDS as one of infectious diseases that can attack next generation of the nation with a variety of diseases accompanied. This became endemic in 34 provinces in Indonesia and can attack anyone in behavior and situations that are prohibited such as promiscuity, free sex, the use of narcotics together, and same-sex sexual. Prevention and treatment of HIV / AIDS is very necessary, especially 
through among key populations. The MARPs is a high-risk group for HIV / AIDS. The study aims to be examined the role of HIV MARPs coordinator in preventing HIV.

\section{METHOD}

There were three main MARPs coordinators that were examined using in-depth semi-structured interviews. The data analyzed using content analysis. This type of research is in the form of descriptive research in which researchers want to find out and identify facts or circumstances in the effort to prevent transmission of HIV / AIDS by leaders of key populations in Sidoarjo Regency.

In this study the sampling technique used was by purposive sampling technique. The research conducted from May to September 2018 in Sidoarjo Regency. Data collection methods are divided into two data capture, first primary data and secondary data. Documentation studies include literature studies from similar studies that have been conducted in different locations as well as secondary data studies that are owned by the Sidoarjo regency government through related institution. Observations and interviews were conducted to reveal the understanding of leaders of key

\section{RESULTS AND DISCUSSION}

Health is a human right that everyone should be able to have. This is in accordance with the 1945 Constitution of the Republic of Indonesia. According to Law Number 36 of 2009 concerning Health, health is a state of health that is not only free from disease but also healthy from physical, mental, spiritual and social conditions which influences the life of every person to be able to live productively socially and economically so that the person remains creative in developing ideas and remains productive in producing something that is beneficial to themselves and the community.

Health development is intended to improve the quality of public health and equitable health services at all levels of society. If someone is healthy both physically and spiritually then that person can live productively so that they can benefit both themselves and the surrounding. The availability of facilities and infrastructure in the health sector will affect the quality of quality and efforts in developing health in Sidoarjo Regency. With the support of the Number of Health Service Facilities available in Sidoarjo Regency, there were 7,427 health facilities recorded in 2016 including General, Special Hospitals, public health care centre (Puskesmas), Medical Centers, Posyandu, and Village Health Posts. The support of also come from health workers in 2016 reached 4,981 people, it shows the seriousness of Sidoarjo Regency in improving the quality of health for the people of Sidoarjo Regency.

Clinical management of HIV / AIDS infections is concentrated on general therapy and special therapy which includes recommend the patient to rest and minimize the level of fatigue due to chronic infection, adequate nutritional support based on macronutrients and micronutrients, counseling including psychological and psychosocial approaches, motivation and supervision in providing antiretroviral therapy (ARV), familiarizing a healthy lifestyle among others by exercising lightly and regularly, preventing sexual relations with multiple partners.

Most female sex worker groups in Sidoarjo Regency have been supervised and VCT checks, health counseling, and 3 monthly health chek-up by the Health Office in collaboration with sub-district public health care centers, AIDS Controlling comission and NGOs in Sidoarjo Regency. The existence of female sex worker means that there is an opportunity for sexual relations between partners without using a condom, which creates the risk of spreading HIV / AIDS.

\section{Coordinator of Key Population's Perception of Population}

\section{Understanding Hazard of HIV and AIDS}

The coordinator of the MARPs who was the respondent of this study was clearly able to explain about HIV. Even though the respondent did not have high level of formal education. This is due to their sense of concern and empathy for people with HIV that ignites the spirit of learning and knowing everything related to HIV.

"... If there is no sign of HIV, so I reach (her) out. After I reach out, I will give information regarding her work, include in high risk (of HIV). I told you, I gave information that her work was at risk, she would want to be tested by VCT. If indeed she is willing, to go (for checkup) then go, ....I will prepare the place here. If she lived here, I will immediately take her to the nearest Puskesmas. I will help her to make appointment with the health pofession. So then, for example there are those who are $\mathrm{R}$ or positive, we immediately follow up ..."

From the interview, it appears that the coordinator of MARPs has the awareness and understanding of the risk level of these workers toward HIV. In addition, the coordinator also explained the dangers of HIV transmission through needles.

A: "I mean, how often, education is obtained by your friends from the community about HIV / AIDs prevention?". F: "Yes we more likely explained about needles anyway, sterile needles. Don't use unsterile needles anymore."

Stigma and discrimination are one of the obstacles in tackling HIV / AIDS, and usually arise due to the wrong perception of society about HIV / AIDS and the public has not gained a comprehensive understanding of HIV / AIDS. Some people still have the perception that HIV / AIDS is a contagious and embarrassing disease (disgrace), and those infected with HIV must be shunned and exiled.

A: "Alhamdulillah, there are many people who want go for VCT, how about the people who still not willing to VCT, why are they miss?

$\mathrm{K}$ : "... Because they might afraid of the results, the reason they are afraid because they are not ready to face the results. Because if they know, my friend, oh my God, ....That's how it is. they are afraid of the results and not ready to accept the reality. " 
The existence of stigma and discrimination against HIV / AIDS found in the community causes some of those who have had experience or who have a risk of HIV / AIDS transmission behaviors to feel scared and ashamed if convicted of HIV / AIDS. The stigma has begun to diminish with the phenomenon that HIV / AIDS does not only attack those at risk.

$\mathrm{K}$ : "The problem of HIV about society in the past was very discriminatory, the stigma about HIV society is like a disgusting specter, that's how it is. But now with lots of information from the community and from many sources. The people begin to understand. Because HIV doesn't just attack a transsexual or gay person. Pregnant women, or even all groups in the society. Because almost now it is true that all can be infected with HIV, which in the past had been caused by disease. ... now it's change by the time .."

\section{The Impact Caused by HIV/AIDS}

The MARPs coordinator in this study really understands all the impacts that can be caused by suffering from HIV / AIDS. The most feared by those who have been identified is the emergence of social sanctions and negative stigma if their status is known. The coordinator of MARPs also has the role to maintain confidentiality other than outreach and companion.

"Most of the people who are positive with HIV are closed (keep the information for their self), then later worry with the future if they are die, please don't let my family know about this.... so that, you have to consume the medicine routine. Don't let me hard to find you when the puskesmas want update from your medication process. Because it would make me ask about you to many people and would trigger the other curiosity about you."

\section{MARPs Coordinator to Prevent Transmission of HIV}

The feeling of empathy shown by the coordinator of MARPs is a positive asset to raise the awareness of people with HIV / AIDS to be willing to follow the treatment procedures that will be undertaken.

"Yes sometimes I sometimes complain to myself "O God I feel pity with them". Sometimes I cry, when they said "Ma'am, am I going to dead? I said, please dont talk about dying unless you have consume the medication routine. , some of the people has stop working as the female sex workers. The people with HIV still can work as usual...such as selling ice, rujak (javanese sald), but unfortunately they did not consume the medication. And now many of them are positive with HIV."

In the interview above the MARPs coordinator plays an important role in building the confidence among the people with positive HIV to recover and start a new life.

\section{The Role of MARPs Coordinator}

\section{Closeness with the sufferers}

The MARPs coordinator must be able to position themselves as parties who have concern for the MARPs because of the risk of contracting with HIV / AIDS. If there is a close emotional bond in communication has formed between the coordinator and the person at risk, so than the dependence arises and make easier to provide knowledge and information about the risks of their work. It appears that the coordinator of MARPs were very concerned so that the the MARPs believed and were willing to consult.

"Yes, I monitored, I have been assisted and also asked her some question. As the reachor, assisting the sufferer consume the medication (Medication Consumption Supervisor). Our job is very complicated. You know right? ... For example, after consume the medicine, there is the side effect such as dizzy, nauseous, and often I ask "what happen with you?" most of them stopped to consume the medicine.... "oh my, if I consumed this medicine, I could not go for work, and then how about my family ? So than, most of them stopped the medication.

Closeness is an important thing sought by the coordinator of key population, so there is trust from vulnerable groups who are willing to share and want to be directed.

"Alhamdulillah, and because of the frequent presence of role models. If there is someone who sick, we invited their friends to visit. It turns out like this, they finally opened "Allrght. Please accompany me to the puskesmas tomorrow" Before I become like this, they have been motivated by visited someone who is sick... Because they often get information, you know. When I was "playing" I forget to give a condom. Automatically they feel risky ..."

The people at risk also has the tendensy to choose which puskesmas to have VCT. The coordinator of MARPs also can understand the motivation among the surferrers decision.

"Why did your friends choose there? Yes besides comfortable with the officers, after they have VCT, then they go for walk around those places. We always get together when we go to the puskesmas, and go directly after it".

\section{Proactive Strategy by the MARPs Coordinator}

In their capacity as an outreach and companion, patience and perseverance are needed in approaching vulnerable groups. Sometimes, their sacrifices made are also in vain.

"Until I ever give a ride one by one from five all friends. It was because too difficult to make them to come to the puskesmas, arent they? Although they have already get my cellphone number, they still have some reason to get away such as "I am in a hurry, because I have a guess to come", and then I offer to come to visit for the next Wednesday, but they still cannot and say other reason. ...sometimes I am tired, but sometimes I feel so pity with them. Because sometimes, I see their sorrow when one of them said "if, I morally convicted of HIV, I must consume the medicine a whole of my life".

In addition, a variety of more dynamic approaches are also applied by MARPs coordinator so that vulnerable targets or groups have the convenience of MARPs along with existing health services.

"When they are in health services, accessing services, whether it is VCT or check for infections of sexual disease services, they will surely get information provided by the counselors. Educate them regarding the use of their drugs, 
then related to the direction of rehabilitation, what should we do if we want rehab, we suggest it to our place. "The syringe is free now, already given from the government from the Ministry of Health already there, a program like that. We are collaborating with the Ministry of Health, so now e ... the needle program if previously placed in trusted institutions only for the program"... But now is more emphasis to make the needs to take it in the puskesmas directly from the service provider"

The support given to the MARPs will motivate them to want to check VCT.

"Supposedly, if in the past they had to be accompanied by field officers. But now, they don't have to, because they have to be independent too. If I do not have any activities, there are no other activities, but I'm the one who accompany them. It's okay, they are even more happy when someone is hanging out with them ... They said that they are more comfortable if they have accompany. If they really do. When it comes to VCT time, I share on whats ap and facebook. like yesterday, for friends who wants a free VCT test come here. They immediately came, commented to my status, joined. So right now the information by face to face is rare, but for social media it's already crowded. So they want to. "

\section{Coordination with Government and Foundations}

Vulnerable groups that receive support or who do not have support from outreach workers have the same opportunity to not practice condom use, this is likely due to the outreach process to vulnerable groups that are still less routine. Based on information obtained by outreach staff due to still lacking and is not proportional to the number of hotspot locations, the lack number of field staff can have an impact on knowledge about condoms, sexual transmitted disease and HIV / AIDS. Knowledge can form certain beliefs so that someone behaves according to those beliefs. Sources of knowledge can be obtained from various sources, one of which is field officers. In addition to the lack of outreach staff, the barriers on MARPs mobility also became the factor of outreach process.

"Usually what are the role of the government (puskesmas, health department) has been done? Besides examination. ... I think that from the puskesmas gives ARV is enough .... Counseling? ... Nothing. Have you gathered or what? ... Nothing ... How about direct visit? ... Yes, if about direct visit, I did it by myself. Only me. there is no from puskesmas."

Indeed, still there is a very limited volunteer for MARPs and it is not possible to reach all regions. From the observations of researchers on the MARPs coordinator who became a guest speaker, he has worked optimally to reach out and assist all known MARPs. In this case, the MARPs coordinator still feel overwhelmed by many issue that need to be addressed so that they expect that the government works on a massive and there should also be more serious structuring in efforts to prevent HIV / AIDS by the government. In addition, some programs still need to be adjusted again because in the drug user group, still dominated by the mindset of getting reward in implementing a program compared to the mindset of achieving health.
"Back then was easier for me to invite them. There is self awareness. But why I said that this program has broke the program quality from the beginning we have arranged and organized the previous programs, now it is destroyed because of one. Now there is, sorry to say the term of money for transport...." So every time, they thinking since the beginning they have to go for having check in puskesmas, they will directly ask how much will I get? "So because of the money for transportation, became exist an additional motivation." This is it, it is our duty together to change this mindset. Because its ever happen the puskesmas want to held a Focus Group Discussion, the other one had ordered food, just because the money for transport had not been given, they spread the issue, you didn't get the transportation money."

The coordinator of MARPs as the important person as the source of information, trustworthy, and pro-active. The perception of MARPs coordinator toward HIV severity has been good enough. However, the perception among the society will affect the perception of key population. The stigma and the social judgment make the coordinator be the trustworthy person for keeping secret. HIV Prevention among the MARPs coordinator has been important role especially by showing their empathy to motivate the HIV suspect or patient to access the public health care.

A Potential body fluids for transmission of HIV are blood, seminal fluid, vaginal fluid, and breast milk. In general, the risk of transmission of HIV / AIDS occurs through sexual contact (homosexuality or heterosexuality). Transmission through blood is usually mediated by blood transfusion / blood products, syringes or other medical devices (drugs, tattoos), perinatal (pregnant women to the fetus) [4].

The spread of the HIV virus can be through activities that involve contact with body fluids [5]. HIV can transmitted through body fluids, semen, vagina, breast milk, cerebrospinal, synovial, and amnion [6]. Prevention of HIV might happen by avoiding sexual relations with people with HIV or people suffer AIDS, prevent the relationships and intercourse with partners who are the same gender or with people who have multiple partners, avoiding sexual relations with injecting drug addicts, prohibiting those who are included in high-risk groups to conduct blood donations, provide blood transfusions only for patients who really need them, and ensure the sterility of HIV and AIDS syringes as the prevention of infectious diseases [7]. HIV is not transmitted through handshakes, kissing, using cutlery, cooperation, sharing a room, mosquito bites, and ordinary social contact [8].

Moreover, the comfort and politeness of the officer's attitudes and behavior in providing services to the community in a polite and friendly manner as well as mutual respect can determined which public health care service will the MARPs chose [9]. The closeness between MARPs and the coordinator build the dependency from the member to the coordinator. Moreover, according to the previous study the female sexual worker also consider the completeness of the services given by the public health care centre [10]. 
[4] Nursalam, Kurniawati. 2009. Asuhan Keperawatan pada Pasien Terinfeksi HIV/AIDS. Jakarta : Salemba Medika.

MARPs coordinator play an important role in reaching out and assisting people at risk of contracting HIV / AIDS which include in coordinating the population at risk of HIV to get public health care service. The recommendation from the study result of the coordination need to outreach larger MARPs so that the public health care or the health department can give more information about HIV to broaden area.

\section{ACKNOWLEDGMENT}

We thank the cooperation and good work of Health District Department Sidoarjo Regency for providing support and information toward the key information.

\section{REFERENCES}

[1] Kementerian Kesehatan RI, 2008. Perkembangan HIV/AIDS di Indonesia. Jakarta: Ditjen PPM \& PL Kemenkes RI.

[2] Kementerian Kesehatan RI, 2013. Laporan Situasi Perkembangan HIV/AIDS di Indonesia. Jakarta: Ditjen PPM \& PL Kemenkes RI.

[3] Komisi Penanggulangan AIDS (KPA) Nasional, 2013. HIV/AIDS di Indonesia. Jakarta: KPA.
[5] Farnan, R., \& Enriquez, M., 2012. What Nurses Know HIV/AIDS : The Answer You Need From The People You Trust. Demos Medical Publishing, New York.

[6] Ahluwalia V.K, Ahluwalia M. 2005. HIV/AIDS transmission, prevention and alternative therapies. New Delhi: Lotus Press.

[7] Widoyono. 2005. Penyakit Tropis : Epidemiolgi, Penularan, Pencegahan, \& Pemberantasannya. Semarang : Erlangga Medical Series (EMS).

[8] KPAN. 2011. Buku Laporan Pertemuan Nasional AIDS 2011. Jakarta : Komite Penanggulangan AIDS Nasional

[9] Yunevy, Eka, Fitri, Haksama, Setya. 2013. Analisis Kepuasan Berdasarkan Persepsi dan Harapan Pasien di Puskesmas Medokan Ayu Surabaya. Jurnal Administrasi Kesehatan Indonesia. Vol 1 (1). Hal 9 20.

[10] Haksama, Setya. 2002. Analysis of Commercial Sexual Worker's (CSW's) Behavior in Getting Health Services in Sexual Transmitted Disease (STD's) Clinic Putat Jaya Surabaya. Jurnal Penelitian Medika Eksakta. Vol 3 (1) 